\title{
Peter and Elaine Moss: Franchisees
}

Ross A. Malaga, Montclair State University, USA

Ram Subramanian, Montclair State University, USA

\begin{abstract}
Peter Moss, a business school professor, and his wife, Elaine, a corporate executive, bought a Hair Shear franchise in the suburban Maryland area in July 2007. Hair Shear was a national chain of over 2,000 stores, all of which were franchisee owned. Peter and Elaine Moss contracted with Philip Levinson, a commercial real estate agent authorized by Hair Shear, to obtain a suitable location for their franchise. During her training session at Hair Shear headquarters in Kansas City, Missouri, Elaine learned of the importance of a good location for the success of the franchise. The first location identified by the real estate agent did not work out because the strip mall's main tenant, a day spa, vetoed the entry of a hair dressing salon, considering the salon to be a competitor. Elaine Moss identified a second location only to be told much later by the real estate agent that the location was taken by a barber friend of the landlord. Disappointed by their inability to find a suitable location, the Moss' met a couple who owned multiple Hair Shear stores in Maryland who suggested that they typically negotiated directly with landlords. This couple suggested a third location for the Moss' to consider. The dilemma facing Peter and Elaine Moss is two fold: "which of the two was the ideal location for their store?" The larger question was," should they bypass the authorized real estate agent and negotiate directly with the landlord?"
\end{abstract}

Keywords: Franchising; Location decision; Break-even point.

\section{INTRODUCTION}

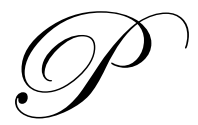

eter Moss was visibly annoyed. It was the morning of February 6, 2008, and Moss was driving through dense traffic on his way to teaching his database management class at the local university. What had annoyed him, though, was not the traffic, but the phone call he just received from his wife, Elaine. Elaine had just found out that a Hair Shear salon was scheduled to open in the Waverly strip shopping center. "Can you believe it, Peter? Phil told us that the landlord already had a deal for a barber shop at that location. We wanted it for our own Hair Shear salon and now somebody else got it for exactly the same purpose. What's going on here? We found that location and told Phil about it. Heck, our kids are in daycare right in that shopping center." Peter was livid. He said, "I have a good mind to go around Phil and negotiate a deal directly with the landlord at White Marsh Plaza." Elaine, ever alert to the dangers of talking and driving at the same time, cautioned her husband to relax and told him to come back home after his class to talk things over. Peter agreed, but as a way to take out his frustration, he took out the business card that read, "Philip Levinson, Commercial Real Estate Agent" ripped it to shreds and threw it out the window.

It was later in the day when Peter and Elaine had a chance to consider their options. Peter's anger at Phil had not cooled and he maintained that the couple should go ahead with their plan to open a Hair Shear salon at the White Marsh Plaza location. Elaine was worried that going around the franchisor's designated real estate agent for the territory would lead to not getting the best deal possible and possibly sour relations with the real estate agent for any future franchise locations. "Besides," said Elaine, "is the White Marsh Plaza location the ideal one for us? Isn't Waverly better? Shouldn't we trust the judgment of a real estate expert who has worked with Hair Shear franchisees before?" "I understand, Elaine, but Phil was contracted to find us a location in this market area. I don't trust him to go bat for us in any negotiations. He has failed us on two previous occasions and look what he has done now? He has obviously helped another Hair Shear franchisee to find the very location that we and he were looking at. How can we trust him now?" 
While the couple was going back and forth on this issue, their two young children came back from school. Soon they were engrossed in parenting issues and when they got a moment alone, Elaine and Peter agreed to finalize their decision the following day.

\section{BACKGROUND}

Peter Moss was a business school professor teaching courses in database management at a local university. Elaine Moss worked in the corporate lending area for a large national bank. They lived in the town of Columbia, Maryland. Peter and Elaine were parents of two girls, both pre-schoolers. While balancing work-life demands occupied much of the Moss' time, of late Elaine had been unhappy at work. She had, in her opinion, a very ornery boss, who took great pleasure in screaming insults at his subordinates at frequent intervals. In addition, Elaine had reached a point in her career where any upward movement called for significant travel. She had reluctantly settled down in her position, but was harboring thoughts of quitting her job and starting something of her own. Both Peter and Elaine realized that Elaine's high paying job was too good to give up unless they could make it up via a business venture.

\section{FRANCHISING}

Franchising is a business system where an entrepreneur is able to purchase a proven business concept, receive training, support, and often the use of a well-known trademark. In return the franchisee (entrepreneur) agrees to pay an up-front fee and a portion of on-going revenues. A number of large companies had built their businesses on the franchising model, most notably McDonalds.

A company that wants to expand via franchising has to provide potential franchisees with a Uniform Franchise Offering Circular (UFOC). The UFOC contains 23 categories, such as litigation history, fees, obligations of the franchisee, obligations of the franchisor, and earnings claims. While each UFOC is required to contain all 23 categories, many companies do not make specific earnings claims. One study pointed out that only 20 percent of U.S. franchisors made verifiable statements regarding the amount of income that the franchise was likely to generate.

\section{THE DECISION TO FRANCHISE}

Peter and Elaine looked into numerous business opportunities. At first, they were interested in day care centers as they had two small children. However, after exploring the purchase of a center or opening their own, they discovered the economics were not favorable.

During a neighborhood barbeque on Memorial Day 2007, Elaine began talking with her neighbor, Meredith Case. Meredith had recently become a franchise consultant and offered her services to Elaine. After a bit of research, Meredith came back with two ideas.

The first idea was to own a commercial cleaning franchise. However, Elaine rejected this idea almost immediately as she realized that she would need to spend a great deal of time on sales calls - an unattractive prospect.

The second idea was to open a Hair Shear salon. Hair Shear was founded in 1985 in Kansas City, Missouri. By 2008, the company had grown to over 2,000 salons throughout the United States and 17 salons in Maryland. Unlike other companies, which typically had company and franchisee-owned locations, all Hair Shear salons were owned by franchisees. Hair Shear salons catered primarily to low to middle income families. Their main customers were men and children.

\footnotetext{
* Scarborough, Wilson, and Zimmerer, Effective Small Business Management: An Entrepreneurial Approach, $9^{\text {th }}$ edition, Pearson Prentice Hall, 2009.
} 
At first, this, too, did not seem like a good fit. Neither Peter nor Elaine knew anything about cutting hair or the salon industry. However, Hair Shear had two major advantages over many of the other business opportunities they had seen. First, it did not require Elaine to leave her job immediately to run the business. In fact, the salon would be run by a full-time manager who was also a hair stylist. Hair Shear would provide support in hiring a manager and would train all employees on the company's specific hair cutting techniques.

Second, Hair Shear's UFOC made specific earnings claims. The claim was that an individual salon should earn about $\$ 60,000$ per year in pre-tax profit. While this was significantly below Elaine's salary at the time, the couple felt they could quickly expand into a second salon. With two salons, Elaine could quit her job and focus on the business.

Peter and Elaine decided to take the next step and speak with current Hair Shear franchisees in their area. All of the franchisees owned multiple salons and most of them were doing very well financially. The franchisees all confirmed that the salons took a minimal amount of time each week to run. The franchisees also imparted the wisdom that the right location could make or break a Hair Shear salon.

Based on all of the information they had gathered, the Moss' decided to become Hair Shear franchisees in July 2007. The franchise fee was $\$ 20,000$, with half due up-front and the other half due when the first salon opened. In addition, they would have to pay $\$ 5,000$ to the Hair Shear advertising fund. This was a fund controlled by the parent company and used to purchase national advertising. For example, Hair Shear used part of these funds to sponsor a NASCAR driver. Hair Shear franchisees were also required to spend $2 \%$ of their monthly gross revenue on advertising. In addition, once Maryland reached 20 salons, it would receive money from the advertising fund to purchase regional ads on local radio stations.

After careful analysis, the Moss' anticipated that the cost of opening the first salon would be approximately $\$ 120,000$. That total included the franchise and advertising fees, as well as leasehold improvements, furniture, fixtures, and signage, grand opening events and advertisement, inventory, and startup labor costs.

In early August 2007, Elaine flew to Kansas City for franchisee training. During her three intensive days there, Hair Shears business processes were explained in detail. She learned things like dealing with Hair Shear's proprietary salon computer system, proper cash management, employee scheduling, marketing strategies, and the process of hiring employees. Elaine paid careful attention to the lecture on choosing the best salon location.

\section{UNDERSTANDING THE IMPORTANCE OF LOCATION}

During her training session, Elaine learned a number of important facets to consider when choosing a location for her salon. First, it was recommended that she avoid locating her salon in a mall. While malls attracted a large number of people, the rent was usually too high to generate an adequate profit. In addition, most people did not want to deal with mall parking and traffic just to get a hair cut.

Instead of malls, Elaine was advised to look at strip shopping centers that contained a grocery store as the anchor. These sites had ample parking, attracted people on a weekly basis (as they purchased groceries), and the rents were fairly reasonable. A strip center with a video store or a large retail chain (e.g., Wal-Mart, Target, etc.) was especially desirable.

Another important consideration when choosing a site was traffic flow. A site that was easily accessible to homeward bound traffic was far better than one that was accessible to traffic heading toward work. This was because most people would not stop on their way to work to get a haircut, but were likely to stop on the way home.

The demographic profile of the area was also an important consideration. The area should have a large number of families located nearby. So, commercial and industrial areas were not considered good locations. A densely packed residential area - townhouses and apartments - was ideal. Also, areas where new housing was being built were generally good locations. Finally, for Hair Shear, the ideal demographic was lower to middle income families. Higher income families tended to get their hair cut at more upscale salons. 
During her training, Elaine asked how far the salon should be located from the nearest competition. Unfortunately, there was no good answer to that question. The trainer told her about a salon that was located right next to a barber shop and doing very well. However, the trainer indicated that when possible, the Hair Shear salon should be the only hair cut establishment in the strip center.

Finally, the trainer went over some things to think about when negotiating a lease with the landlord. In addition to the monthly rent, the trainer pointed out that in some cases, a landlord would pay for leasehold improvements. Leasehold improvements were fixtures, lighting, flooring, etc. that were actually installed on a permanent basis to the site. For a hair salon, typical leasehold improvements included additional plumbing for sinks, special flooring, and cabinets. These could easily add up to $\$ 50,000$ for a typical Hair Shear salon.

Another negotiating point was when lease payments actually began. In some cases, a landlord would charge rent while the establishment was still being built out. Others would give a grace period of up to several months after opening before lease payments began.

In addition, proper signage was vital. A sign above the actual salon was essential. But, Elaine learned that a sign on the pedestal (the large sign near the street that listed all of the stores in a strip center) was also important and not always included as part of the lease.

\section{HAIR SHEAR'S REAL ESTATE SUPPORT AND RULES}

As Elaine was flying back to Maryland, she thought about how complex choosing a location and negotiating a lease was. She was glad that Hair Shear provided real estate support. The day after Elaine returned, she and Peter called Hair Shear's designated commercial real estate agent in Maryland, Philip Levinson.

Philip explained his role and the rules surrounding choosing a location. First, he explained that he worked for a commercial real estate firm and not for Hair Shear directly. In his role with the firm he represented all Hair Shear franchisees in Maryland, as well as numerous other clients.

Philip told the Moss' that each week he sent out a list of all available commercial real estate in Maryland that met the needs of Hair Shear franchisees. The list was sent out every Monday morning via e-mail. If a franchisee saw a good location, they called corporate headquarters and reserved it. This gave them first rights to the site. Franchisees could only reserve one site at a time. Philip explained that the franchisee should then call him so that he could begin negotiations. He further explained that if the franchisee had any contact with the landlord before contacting him, he would not be able to represent the franchisee.

\section{CHOOSING A LOCATION}

On Monday, August 6, 2007, the Moss' received the weekly real estate e-mail from Philip. One site immediately jumped out at them. A new strip shopping center was going to be built right next to Arundel Mills Mall. Arundel Mills Mall was a large outlet mall with a multiplex movie theater and restaurants that the Moss' frequented. In fact, their favorite restaurant was in the mall, so they knew the area well.

They immediately called Philip to get more details about the building site. That evening they decided to drive out to examine the site and get a bite to eat for dinner. The site seemed perfect. The mall generated a huge amount of traffic, particularly on weekends. But, the strip center was located across from the mall with its own parking lot. The strip was going to be anchored by a Safeway grocery store. It was convenient to two major highways, so it would have a lot of going home traffic. In addition, new houses were being built in the area. The only drawback was that the rent, at about $\$ 30$ per square foot, was on the high side.

The Moss' discussed the location over dinner and decided to jump on it. Although the rent was high, the site had the potential to generate a great deal of traffic for the salon. The next day Peter called corporate headquarters and reserved the site and then called Philip and told him to begin negotiations. 
After that, the Moss' waited, and waited, and waited some more. Every week or so they called Philip, who explained that since the site needed to be built the landlord was not yet negotiating leases. On October 10, 2007, Peter called Philip once again to check on the status. Philip told him that a large day spa had negotiated space in the strip center and did not want a hair salon. Peter suggested that Philip talk with the day spa owner as a Hair Shear salon was not really direct competition and, in many cases, complemented each other. Philip indicated that the landlord had made his decision and it was final.

\section{CHOOSING ANOTHER LOCATION}

About two weeks later, Elaine was picking up the kids when she noticed a "space for rent" sign in front of the strip center where the day care facility was located. The landlord was extending the strip. When she arrived home, she checked the real estate list for the week, but the strip center was not on it. This was a chance to jump in front of all the other franchisees.

Elaine and Peter discussed the new location. Elaine pointed out that it was a grocery anchored strip center in a new housing development called Waverly (Exhibit 1 contains a map and Table 1 the demographic data for this location). The development consisted of single family homes, a few townhouses, and a small apartment complex for senior housing. Peter pointed out that besides this development, the rest of the area was fairly rural. Elaine argued that the site was very good for going home traffic, as she was often stuck in it when going to pick up the kids. Another factor was that the rent was pretty low, at about $\$ 15$ per square foot. One final advantage was that since their kids were in day care in the strip center, it would be very convenient to check on the salon on a daily basis.

\section{EXHIBIT 1}

\section{Map of the Two Locations}

\section{Locations Overview}

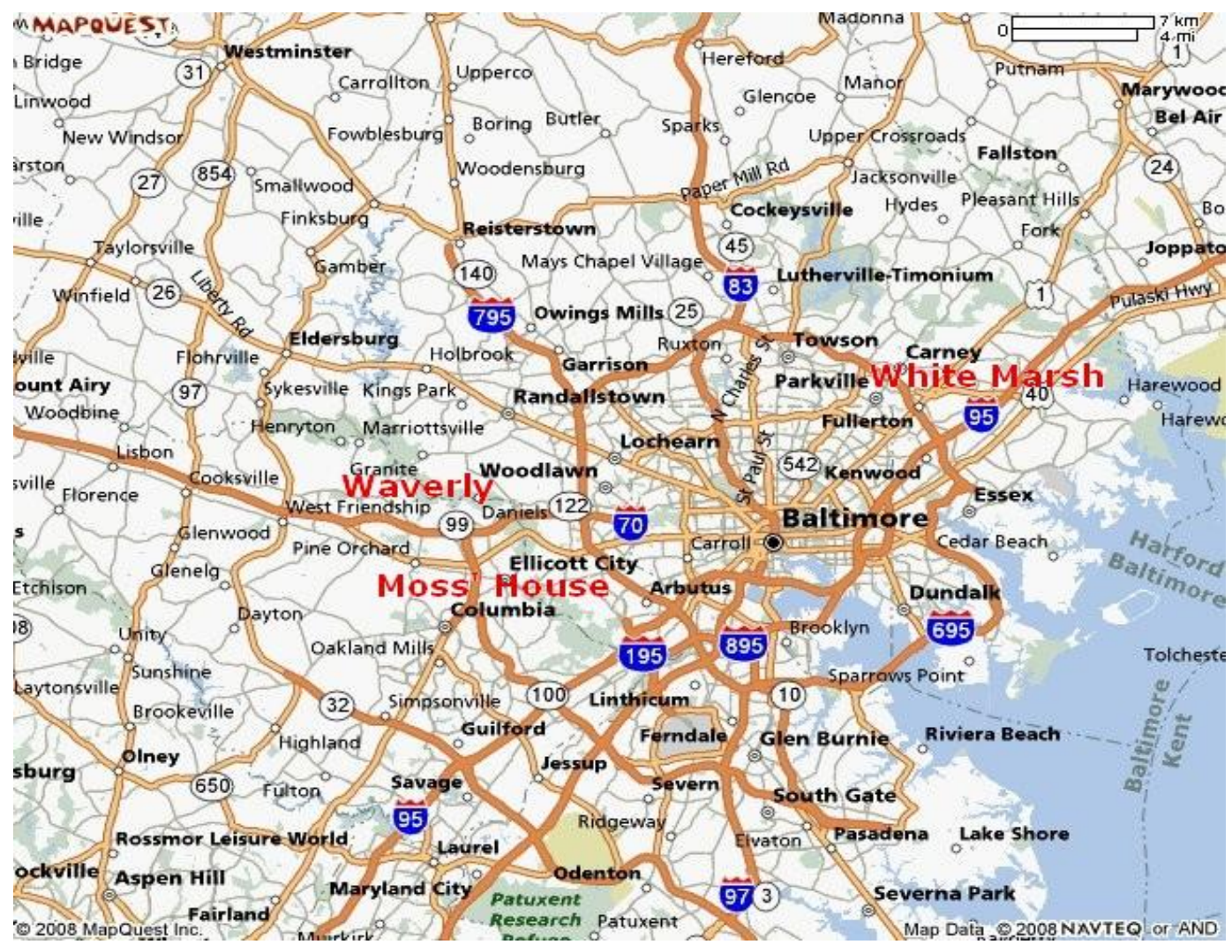



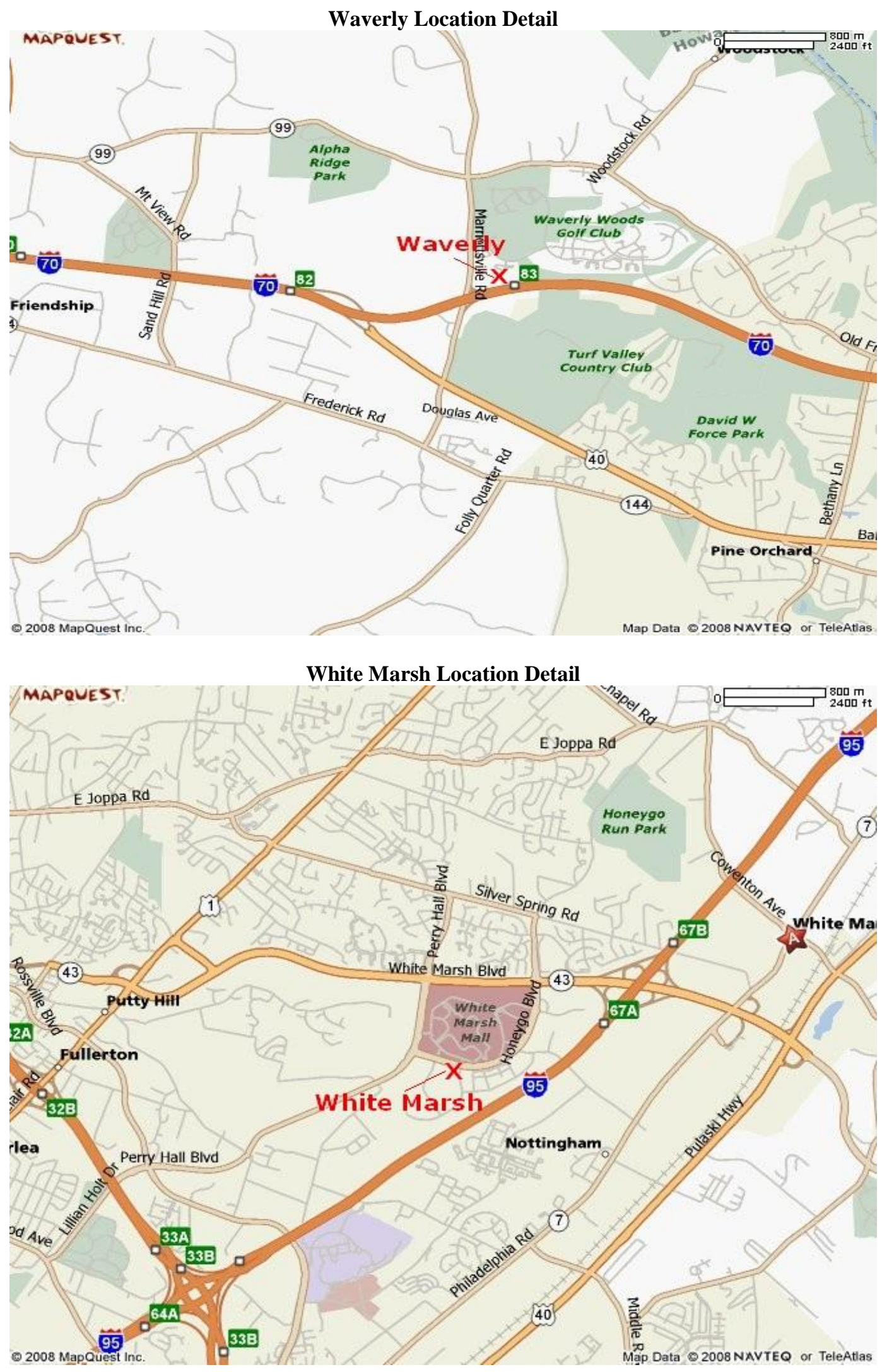
Table 1

Demographic Details of the Locations

\begin{tabular}{|l|c|c|}
\hline Location & Waverly & White Marsh \\
\hline ZIP Code & 21104 & 21237 \\
\hline County Population & 275,009 & 793,756 \\
\hline City Population & 4,736 & 9,047 \\
\hline Median Household Income (\$) & 92,390 & 47,916 \\
\hline Percentage Using Car to Work & 84.5 & 82.5 \\
\hline
\end{tabular}

Source: Adapted from FreeDemographics.com. Data is from Census Year 2000.

The Moss' decided to reserve the Waverly location. They called corporate headquarters and then called Philip. The next day, Philip called back to say that the landlord had already promised some of the new space to a barber friend of his. The Moss' removed their reservation on the site and began to look for another location.

\section{CHOOSING ANOTHER LOCATION AGAIN}

At this point, the Moss' decided to seek out a little extra advice. They invited Susanne and Jim Sloan over for dinner. The Sloan's already owned seven Hair Shear salons in the area and were very successful in running them. Jim volunteered that he no longer used Philip, but negotiated with landlords directly. He informed the Moss' that Philip had a number of very large accounts and did not really pay much attention to Hair Shear franchisees. The Sloan's recommended that the Moss' look at a new location - White Marsh Plaza (a map and demographic data for this location can be found in Exhibit 1).

In many ways, White Marsh Plaza was similar to the Arundel Mills location. It was a grocery anchored strip shopping center across from a very large regional shopping mall. The site would have a huge amount of visibility on the weekend when the mall was typically packed. However, the site was not convenient to most residential areas and the mall traffic might deter those who just need a haircut. The demographics in the area were generally good. A large number of military families from the nearby Aberdeen Proving Grounds (about 10 miles away) shopped at the White Marsh Mall. While military families tended to get more haircuts, how many would choose Hair Shear was unknown. The rent for the space was quite high at about $\$ 35$ per square foot and, due to the layout of the building, they would need to take more space than they would actually need - about 2,500 square feet as opposed to $1,800-2,000$.

\section{THE BIG QUESTION}

The Moss' had not decided what to do when Elaine received the latest real estate e-mail list from Philip, which left her dumbstruck. The very first listing said "Waverly" and next to that, "Smith", the name of another franchisee in the Maryland area. She immediately called Peter. When she got off the phone with Peter, she called Philip absolutely furious. Philip explained that Bob Smith had called the landlord at Waverly directly and convinced the landlord to go with a Hair Shear instead of a barber shop. Elaine pointed out that Philip should have done that for the Moss' in the first place. Philip told Elaine to calm down as Bob Smith had a habit of reserving locations and then backing out a month later. As soon as Bob Smith backed out, Philip would call the landlord and get a deal for the Moss'. Elaine wondered to herself how willing the landlord was going to deal with another Hair Shear salon after one had already backed out.

\section{THE DECISION}

When Peter and Elaine had a chance to talk that night, they went over their options. With the help of Hair Shear and the group of Maryland Hair Shear franchisees, the Moss' had come up with cost and revenue estimates for the two locations (as shown in Table 2). They realized that they could wait to see if Bob Smith backed out of the Waverly deal and hope that Philip can get them that location. At the same time, an experienced Hair Shear franchise, Jim Sloan, had suggested the White Marsh location. Should they reserve the White Marsh location as a fallback or to really go after it? If they do reserve White Marsh, should they use the real estate agent or go it alone? As they 
wondered what to do, Elaine sighed and said, "I need to get a good night sleep to work one more day with Mike (her boss at the bank)! Boy, I can't wait to quit and not have to put up with that man's tantrums."

Table 2

Revenue and Cost Projections for the Two Locations

\begin{tabular}{|l|c|c|}
\hline & Waverly & White Marsh \\
\hline Price per cut & $\$ 11.00$ & \$11.00 \\
\hline Product sales (shampoos, etc.) & $7 \%$ of cut revenue & \\
\hline COSTS & & $42-47 \%$ of cut revenue \\
\hline Labor & $40-45 \%$ of cut revenue & $\$ 87,500$ per year \\
\hline Rent & $\$ 22,500$ per year & $2 \%$ of total revenue \\
\hline Advertising & $2 \%$ of total revenue & \$720 per year \\
\hline Telephone & $\$ 720$ per year & $10 \%$ of rent \\
\hline Electricity & $10 \%$ of rent & $\$ 1,000$ per year \\
\hline Insurance & $\$ 1,000$ per year & $5 \%$ of total revenue \\
\hline Franchise fees & $5 \%$ of total revenue & \\
\hline
\end{tabular}

Estimated number of cuts at Waverly $=300-500$ per week

Estimated number of cuts at White Marsh $=550-800$ per week.

\section{AUTHOR BIOGRAPHIES}

Ross A. Malaga is an Associate Professor of Management and Information Systems at the School of Business, Montclair State University. He received his Ph.D. from George Mason University. Dr. Malaga has published extensively in the area of electronic commerce in Communications of the ACM, Electronic Commerce Research, and the Journal of Organization Computing and Electronic Commerce. He serves on the editorial review boards of Information Resources Management Journal and the Journal of Electronic Commerce in Organizations.

Ram Subramanian is a Professor of Management at the School of Business, Montclair State University. He received his Ph.D. from the University of North Texas. Dr. Subramanian has published in a variety of journals including Journal of Management, Journal of Business Research, Management International Review, and Case Research Journal. He serves on the editorial board of The CASE Journal. 